\title{
SMALL TERRESTRIAL MAMMALS LIVING ALONG STREAMS ACTING AS NATURAL LANDSCAPE BARRIERS
}

\author{
TOMÁŠ BOHDAL ${ }^{1}$, JOSEF NAVRÁTIL ${ }^{1}$, FRANTIŠEK SEDLÁČEK ${ }^{2}$
}

${ }^{1}$ Department of Biological Disciplines, Faculty of Agriculture, University of South Bohemia in České Budějovice, Branišovská 31a, 37005 České Budějovice, Czech Republic; e-mail: tomas.bohdal@pfm.cz, josefnav@gmail.com

${ }^{2}$ Department of Zoology, Faculty of Science, University of South Bohemia in České Budějovice, Branišovská 31, 370 05 České Budějovice, Czech Republic; e-mail: fsedlac@prf.jcu.cz

\begin{abstract}
Bohdal T., Navrátil J., Sedláček F.: Small terrestrial mammals living along streams acting as natural landscape barriers. Ekológia (Bratislava), Vol. 35, No. 2, p. 191-204, 2016

Riparian stands along streams are important landscape elements - biocorridors, allowing the dispersal of many small terrestrial mammals. Streams are, however, also barriers limiting dispersal, which leads to isolation and population-genetic changes. Communities of small terrestrial mammals (Eulipotyphla, Rodentia) were studied in 2004 to 2006 on five watercourses of varying widths in Central European cultural landscape situated in South Bohemia (Czech Republic). In total, 547 individuals from 10 species were captured by the Capture-Mark-Recapture method (CMR). Yellow-necked mouse (Apodemus flavicollis) and bank voles (Myodes glareolus) were eudominant species at all locations. Species diversity and equitability rose with the degree of the barrier - proportional to the width of the stream.

The terrestrial mobility of selected species was also assessed. Apodemus flavicollis indicated overall highest values of mobility, and Myodes glareolus males also scored higher values, however, the width of the stream did not correlate with mobility in these species. The animals crossed watercourses on the order of tens of meters wide in the period of 3 months. The frequency of crossing of Apodemus flavicollis decreased exponentially with the width of the stream and was dependent on population density.
\end{abstract}

Key words: barrier, mobility, CMR, Apodemus flavicollis, Myodes glareolus.

\section{Introduction}

Streams, their banks, littoral vegetation and riparian forest are natural corridors maintaining the biological diversity of the landscape (e.g., Rosenberg et al., 1997; Bennett, 2003). In disturbed urban areas and agrocenosis, these corridors constitute suitable habitats for the migration and preservation of the metapopulation structure of many species such as small mammals (Hirota et al., 2004). Flooding, drought, bank erosion, ice abrasion, sedimentation, etc., all influence the dispersal of terrestrial species along watercourses and they help to create in this corridor along the river a heterogeneous environment (Forman, Godron, 1993; Jacob, 2003; Wijnhoven et al., 2005). There is a steep gradient from the water to the terrace. Some 
species utilize the lower floodplains with higher soil moisture for their migration, while other species prefer the higher terraces above the river bank finding the damp environment and regular flooding unsuitable (Forman, Godron, 1993; Andersen et al., 2000).

Watercourses can, on the other hand, form natural barriers and isolate or limit the movement of many species of small terrestrial animals (see Bennett, 2003; Kozakiewicz et al., 2009). The limiting factors of dispersal are always the combination of quantitative (e.g., barrier width) and qualitative (species dependent) aspects of the barrier (Rodriguez et al., 1996). Significant constrictions of passage can limit gene flow between local populations, which can result, on the one hand, in the reduction of genetic diversity, but can, on the other hand, lead to the development of vital metapopulation systems and locally adapted subpopulations (cf. Merriam et al., 1989; Aars et al., 1998; Gerlach, Musolf, 2000; Lugon-Moulin, Hausser, 2002; Keller, Waller, 2002).

Crossing a wide river or even a small stream can present a number of problems for small terrestrial mammals mostly connected with the accumulation of energy for swimming and thermoregulation (e.g., Lugon-Moulin, Hausser, 2002). For various small terrestrial mammals, the barrier effect will differ according to their mobility, life history, and habitat specialization of the species (Wolff, 1999). Therefore we were interested how small terrestrial mammals (members of the taxa Rodentia and Eulipotyphla) deal with the presence of a watercourse located in Central European cultural landscape. We were interested in animals living in close proximity to the streams in riparian vegetation, as well as animals living in adjacent forest stands, and to study them at the species as well as community level. We expected that the population of small mammals, living in the riparian vegetation and the adjacent forest edge on both banks of the stream would be effected by the degree of the barrier, mostly the width of the watercourse, in several ways. Based on data presented in literature, we formulated the following working hypotheses:

1. Species diversity and equitability in the communities of small terrestrial mammals in the segment where we intend to trap them will increase in proportion to the degree of the barrier - specifically the width of the watercourse. This hypothesis is based on the assumption that the wider the stream the greater the influence on the riparian zone resulting in greater heterogeneity.

2. The terrestrial mobility of individual in small terrestrial communities, in the segment where they will be trapped, will increase in relationship to the width of the stream. This hypothesis is based on the assumption that the individuals living in close proximity to the stream will exhibit locomotion activity - mobility - directed in parallel direction with the stream barrier (extended home range) - the smaller the ability for small terrestrial animals to cross the watercourse, the greater the locomotion activity.

3. The number of crossings the stream will be inversely proportional to the width of the watercourse and directly proportional to the abundance of small terrestrial mammals and the level of their terrestrial mobility. This hypothesis is based on two assumptions: (i) the flow velocity of the stream crossing will be low and approximately the same at all the localities, (ii) small terrestrial mammals try to cross the stream as fast and in as short (perpendicular to the flow) a distance as possible. 
This paper is an introduction to zoological-ecological part of the study of river barriers and it will be subsequently followed by a population-genetic study, for dispersal ability and the crossing of barriers subsequently influences in a basic way the genetic structure and demographic processes in the population (e.g., Gaines, McClenaghan, 1980; Stenseth, Lidicker, 1992). The population-genetic analysis of the material which was obtained during this introductory study, as was done by Rico et al. (2007b, 2009). This study should explore the connection between the discovered diversity parameters, mobility, and barriers on one side and population genetic parameters on the other side. The interconnectivity of these approaches will bring new understanding to this area, since the movement of animals does not automatically equate gene flow and gene flow does not automatically let us reconstruct the movement of animals along and across barriers.

\section{Material and methods}

\section{Site description}

The study took place in riparian and adjacent forest habitats along watercourses, situated in South Bohemia (Fig. 1). Five stream segments of different widths, but with approximately the same flow velocity of $1-2 \mathrm{~km} / \mathrm{h}$ were selected: 1) Kozlovský stream (width $3 \mathrm{~m} ; 49^{\circ} 6^{\prime} \mathrm{N}, 14^{\circ} 29^{\prime} \mathrm{E}$ ); 2) the river Černá (width $13 \mathrm{~m} ; 48^{\circ} 45^{\prime} \mathrm{N}, 14^{\circ} 30^{\prime} \mathrm{E}$ ); 3) the river Malše (width $20 \mathrm{~m} ; 48^{\circ} 47^{\prime} \mathrm{N}, 14^{\circ} 29^{\prime} \mathrm{E}$ ); 4) the river Lužnice (width $35 \mathrm{~m} ; 49^{\circ} 23^{\prime} \mathrm{N}, 14^{\circ} 34^{\prime} \mathrm{E}$ ); 5) the river Vltava (width $145 \mathrm{~m} ; 49^{\circ} 08^{\prime} \mathrm{N}, 14^{\circ} 27^{\prime} \mathrm{E}$ ). These localities are located on the middle and lower courses of the watercourses surrounded forest stands and of varying degree of fragmentation of the greater surrounding landscape. The riparian zones were slightly sloping, mostly covered by vegetation with occasional patches of sand or gravel.

Tree and shrub layer, consisting mostly of Norway spruce (Picea abies), black alder (Alnus glutinosa), common oak (Quercus robur), European beech (Fagus sylvatica), willow (Salix spp.), silver birch (Betula pendula), European hazel (Corylus avellana) and blackberry (Rubus spp.) was present at all localities. Riparian habitat included characteristic herbaceous vegetation with preponderance of ribbon-grass (Phalaris arundinacea), quaking grass sedge (Carex brizoides), stinging nettle (Urtica dioica) and patchy occurrence of policeman's helmet (Impatiens glandulifera) and touch-me-not (Impatiens noli-tangere).

\section{Trapping and marking of animals}

Wooden live traps were used to capture small terrestrial mammals. Two $125 \mathrm{~m}$ long lines of traps at $5 \mathrm{~m}$ intervals were placed on each bank parallel to the stream two transect lines 25 live traps at $5 \mathrm{~m}$ intervals. The first line was placed in streamside vegetation, 5 $\mathrm{m}$ from the edge of the water, and the second line was located in the forest vegetation, $10 \mathrm{~m}$ from the

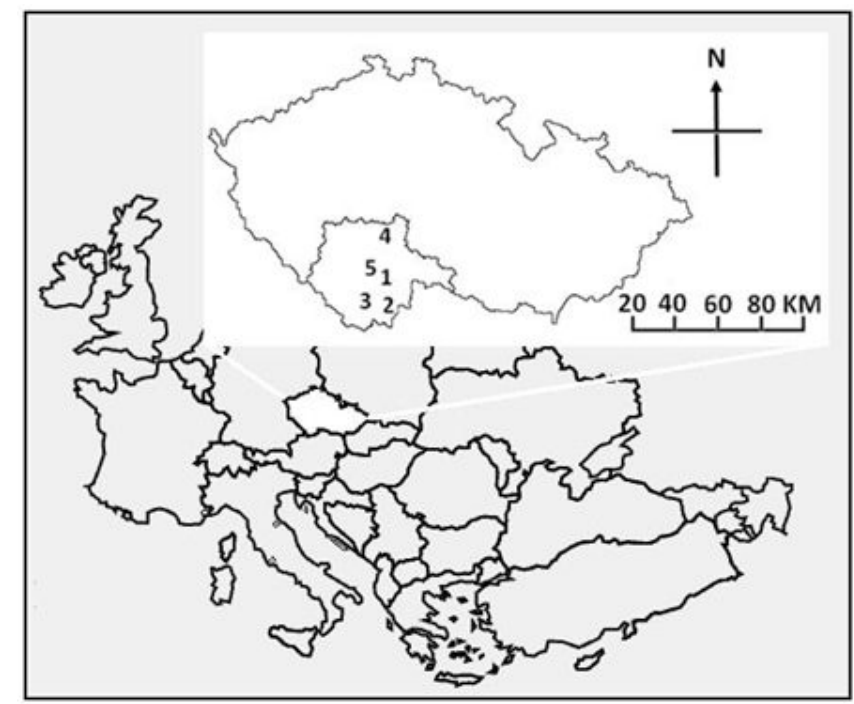

Fig. 1. The location of trapping localities in the Czech Republic. Enlargement: 1 - Kozlovský stream; and the rivers: 2 - Černá, 3 - Malše, 4 - Lužnice, 5 - Vltava. 
water. This placement of traps should have trapped animals at the very edge of the habitat next to the water and to enable us to calculate the index of animals' mobility and along the bank (e.g., Rico et al., 2007a,b). A total of hundred traps were laid on both sides of the watercourse in the selected segment and were baited with a mixture of oats and sardines for four consecutive nights at each site. They were check at regular intervals - 2 hours after dusk, and 2 hours after dawn. Animal trapping was done in 2004-2006 during the summer (first half of June) and the fall (second half of September).

Small terrestrial mammals were captured using the capture-mark-recapture method (CMR - e.g., Pocock et al., 2005). The captured animals were weighted and sexed. Small mammals were, on the basis of physical measurements and breeding condition (e.g., abdominal or scrotal testes distinguished, lactation in females), divided into sub-adult and adult categories. Sub-adult specimens, Apodemus flavicollis and A. sylvaticus, not showing signs of speciestypical features, were identified only to genus (Apodemus sp.). The captured animals were marked by toe clipping and released. A record was kept of the individual animal's number, trap and trap line identification as well as above mentioned data. The obtained tissue sample (toe clipping) was preserved in $96 \%$ ethanol for further study.

\section{Statistical data analysis}

Relative abundance A (\%) - numbers of individuals per 100 trap-nights, and dominance D (\%) - ration of trapped individuals of species to the total number of trapped individuals, were calculated for each species. Further, for the community Shannon's index of species diversity $-H$ ' and equitability $-E$ (e.g., Begon et al., 1990) was calculated. The number of total species $-S$ and relative number of species $-S_{r e l}(\%)$ were also tabulated. Undetermined individuals (Apodemus sp.) were not included in the above mentioned indexes.

Different number of species and individual animals were captured in the capture period in different localities. For easier comparison, the number of species and individual animals were expressed relative to the total number of species and individual animals captured. The differences between the number of captured species, individual animals, the summer, and fall trappings were determined with the help of the analysis of variance (ANOVA). In addition, the analysis of variance was used to test for differences in representation among adults and sub-adults of each individual species. The number of adults and sub-adults were also expressed relative to the number of individual animals of a given species captured at a given locality.

Since only A. flavicollis and Myodes glareolus had sufficient representation in the captured population, only they could have their level of movement activities - mobility ascertained, and have the difference in the aforementioned categories determined. Mobility was established according to Rico et al. (2007a,b) - on the basis of the distance between two, one immediately following the other, captures. It is the distance between the traps, where an individual animal was captured consecutively two times. The evaluation once again used the analysis of variance and Tukey's post-hoc test for different samples sizes.

The differences between the established categories of individual animals, as far as the types of species which experience the barrier effect of the stream, were tested for $\chi^{2}$ goodness-of-fit test with Yates' correction (Zar, 1999). $\chi^{2}$ goodness-of-fit test was also utilized to see if the ratio of males to females (sex ratio - SR) deviated significantly, and if the animals captured in the forest line of traps differed from the animals captured in the littoral line of traps. The relationship between species diversity, equitability, and width of stream were evaluated with the help of generalized linear models (GLM) and likewise the relationship between the number of individual animals crossing the watercourse, width of stream, abundance, and mobility. Specific data is given as the mean \pm S.E. The above mention statistical tests were completed in the Statistica 9 program.

\section{Results}

\section{Species captured}

During the time period from 2004 to 2006, 4000 trap-nights were undertaken. Captured animals totaled 547 specimens out of which 338 animals were captured at least twice. Ten species of small terrestrial mammals were determined: Apodemus flavicollis (211), A. sylvaticus (18), Micromys minutus (2), Myodes glareolus (165), Microtus arvalis (79), M. agrestis (27), Sorex araneus (28), S. minutus (3), Neomys fodiens (2), Crocidura suaveolens (2), Apodemus sp. (10). 
During the summer 209 individual animals were captured, out of which 148 animals were captured at least twice. All these animals belonged to 7 species: A. flavicollis, A. sylvaticus, Myodes glareolus, Microtus arvalis, M. agrestis, Sorex araneus and S. minutus. In the fall 410 individual animals were captured, out of which 238 animals were captured at least twice and 72 of these were already captured and marked in the summer. During this timeframe 9 species were identified: Apodemus flavicollis, A. sylvaticus, Myodes glareolus, Microtus arvalis, $M$. agrestis, Sorex araneus and S. minutus.

During the fall significantly higher number of specimens were captured $(\mathrm{F}=21.98 ; P=$ 0.002). On the contrary, the difference in the number of species captured (expressed as a proportion of the total number of species $S=10$ ) at the different localities and capture periods were statically insignificant (see Table 1).

T a ble 1. Seasonal differences in number of captured species and individuals. The number of species and individuals in the summer and fall capture period are expressed in relation to the total number of species and individuals captured.

\begin{tabular}{|l|c|c|c|c|c|c|}
\hline & \multicolumn{2}{|c|}{ Summer } & \multicolumn{2}{c|}{ Autumn } & & \\
\hline & mean & S.E. & mean & S.E. & F & $P$ \\
\hline Species & 0.70 & 0.06 & 0.86 & 0.06 & 3.8698 & 0.084 \\
\hline Individuals & 0.342 & 0.062 & 0.750 & 0.062 & 21.9830 & 0.002 \\
\hline
\end{tabular}

\section{Community of small terrestrial mammals}

Significant eudominant species of all the observed communities of terrestrial mammals were Apodemus flavicollis and Myodes glareolus, which, with the exception of the Vltava locality, had constantly the highest abundance $(\mathrm{A}=3.1-9.9 \%)$ and dominance $(\mathrm{D}=18.8-61.2 \%)$ values. Both species were regularly captured in the bank vegetation (riparian line) and in the stands of woody species (forest line), even though the differences between the trap lines are statistically insignificant. Microtus arvalis reached the highest values of abundance $(\mathrm{A}=6.9 \%)$ and dominance $(\mathrm{D}=41.3 \%)$ in the locality Vltava, which it probably reached from the close-by agrocoenosis. It was also abundant in the locality Lužnice $(\mathrm{A}=2.0 \%, \mathrm{D}=13.8 \%)$, where it preferred the riparian vegetation habitat to woody plants $\left(\chi^{2}=8.6 ; P<0,001\right)$. Another commonly observed species was Sorex araneus, which was the fourth most abundant species $(\mathrm{A}=$ 0.3 až $1.1 \%$ ). Microtus agrestis was also a stable member in the community of small terrestrial mammals; it was captured everywhere but the Lužnice locality. At the Černá a Malše localities, Myodes glareolus with Apodemus flavicollis were the eudominant species of community $(\mathrm{D}=12.4 \%$, resp. $\mathrm{D}=8.8 \%)$. Waterlogged areas with bushy vegetation Phalaris arundinacea and Carex brizoides apparently represented the optimal habitat. The species, Apodemus sylvaticus, was present, in lower numbers, in all observed communities $(\mathrm{A}=0.3-1.0 \%, \mathrm{D}=$ 1.7-6.0\%). Few in numbers, recedental species observed communities of small terrestrial mammals were represented by Sorex minutus $(\mathrm{A}=0.1-0.3 \%, \mathrm{D}=0.8-1.6 \%)$, Neomys fodiens $(\mathrm{A}=0.3 \%, \mathrm{D}=1.7 \%)$, Crocidura suaveolens $(\mathrm{A}=0.1 \%, \mathrm{D}=0.8-0.9 \%)$ and Micromys minutus $(\mathrm{A}=0.1 \%, \mathrm{D}=1.1-1.2 \%)$. 
Species diversity $\left(H^{\prime}\right)$ and equitability $(E)$ of all communities, with the exception of the locality Kozlovský stream, were roughly equal. Even though Microtus arvalis reached a high value of dominance $(\mathrm{D}=41.3 \%)$, the highest values of species diversity $\left(H^{\prime}=2.18\right)$ and equitability $(E=0.73)$ was obtained in a community of small terrestrial mammals at the locality Vltava.

In contrast, the relatively high abundance and dominance of Apodemus flavicollis ( $\mathrm{A}=$ $9.9 \%, \mathrm{D}=61.2 \%$ ) and the determination of only 7 species was reflected in the lowering of the species diversity $\left(H^{\prime}=1.60\right)$ and equitability $(E=0.62)$ at the locality of Kozlovský stream (see Table 2). This fact was reflected in the regression (log link function) between the width of the watercourse and species diversity $-H^{\prime}$ (Wald stat. 7.3; $P<0.007$ ) and equitability $-E$ (Wald stat. $4.2 ; P<0.040$ ).

T a b l e 2. Overall summary of the presence of different species and their abundance - A (\%), dominance - D (\%), number of captured specimens - $\mathrm{n}$, number of species - $S$, relative number of species $-S_{\text {rel }}(\%)$, diversity - $H^{\prime}$ and equitability $-E$ index.

\begin{tabular}{|c|c|c|c|c|c|c|c|c|c|c|}
\hline \multirow[t]{2}{*}{ Species /Site } & \multicolumn{2}{|c|}{$\begin{array}{c}\text { Kozlovský } \\
\text { stream }\end{array}$} & \multicolumn{2}{|c|}{ Černá } & \multicolumn{2}{|c|}{ Malše } & \multicolumn{2}{|c|}{ Lužnice } & \multicolumn{2}{|c|}{ Vltava } \\
\hline & A & D & A & D & A & D & A & D & A & D \\
\hline Sorex araneus & 0.9 & 5.4 & 0.5 & 4.5 & 0.3 & 2.5 & 0.8 & 5.2 & 1.1 & 6.8 \\
\hline Sorex minutus & 0.3 & 1.6 & 0 & 0 & 0 & 0 & 0 & 0 & 0.1 & 0.8 \\
\hline Crocidura suaveolens & 0 & 0 & 0 & 0 & 0 & 0 & 0.1 & 0.9 & 0.1 & 0.8 \\
\hline Neomys fodiens & 0 & 0 & 0 & 0 & 0 & 0 & 0.3 & 1.7 & 0 & 0 \\
\hline Myodes glareolus & 3.1 & 19.4 & 4.0 & 37.1 & 3.1 & 31.2 & 6.6 & 45.7 & 3.6 & 21.8 \\
\hline Microtus arvalis & 0 & 0 & 0.3 & 2.2 & 0.8 & 7.5 & 2.0 & 13.8 & 6.9 & 41.3 \\
\hline Microtus agrestis & 0.9 & 5.4 & 1.4 & 12.4 & 0.9 & 8.8 & 0 & 0 & 0.3 & 1.5 \\
\hline Micromys minutus & 0 & 0 & 0.1 & 1.1 & 0.1 & 1.2 & 0 & 0 & 0 & 0 \\
\hline Apodemus flavicollis & 9.9 & 61.2 & 4.5 & 40.5 & 4.4 & 43.8 & 4.5 & 31.0 & 3.1 & 18.8 \\
\hline Apodemus sylvaticus & 0.5 & 3.1 & 0.3 & 2.2 & 0.3 & 2.5 & 0.3 & 1.7 & 1.0 & 6.0 \\
\hline Apodemus sp. & 0.6 & 3.9 & 0 & 0 & 0.3 & 2.5 & 0 & 0 & 0.4 & 2.2 \\
\hline Total & 16.2 & 100.0 & 11.1 & 100.0 & 10.2 & 100.0 & 14.6 & 100.0 & 16.6 & 100.0 \\
\hline $\mathrm{n}$ & \multicolumn{2}{|c|}{129} & \multicolumn{2}{|c|}{89} & \multicolumn{2}{|c|}{80} & \multicolumn{2}{|c|}{116} & \multicolumn{2}{|c|}{133} \\
\hline$S$ & \multicolumn{2}{|c|}{6} & \multicolumn{2}{|c|}{7} & \multicolumn{2}{|c|}{7} & \multicolumn{2}{|c|}{7} & \multicolumn{2}{|c|}{8} \\
\hline$S_{\text {rel }}$ & \multicolumn{2}{|c|}{0.6} & \multicolumn{2}{|c|}{0.7} & \multicolumn{2}{|c|}{0.7} & \multicolumn{2}{|c|}{0.7} & \multicolumn{2}{|c|}{0.8} \\
\hline $\mathrm{H}^{\prime}$ & \multicolumn{2}{|c|}{1.60} & \multicolumn{2}{|c|}{1.94} & \multicolumn{2}{|c|}{1.99} & \multicolumn{2}{|c|}{1.91} & \multicolumn{2}{|c|}{2.18} \\
\hline$E$ & \multicolumn{2}{|c|}{0.62} & \multicolumn{2}{|c|}{0.69} & \multicolumn{2}{|c|}{0.71} & \multicolumn{2}{|c|}{0.68} & \multicolumn{2}{|c|}{0.73} \\
\hline
\end{tabular}

\section{Apodemus flavicollis and Myodes glareolus captures}

Both species accounted for $70 \%$ of the total number of trapped individuals. During summer and fall, 211 specimens of the species of Apodemus flavicollis were trapped of which 145 $(68.7 \%)$ individual animals were captured repeatedly and out of these 33 individual animals were captured both during the summer and fall. One individual was recaptured 15 times (evening, morning, summer, fall). Both sexes were represented evenly except during the fall 
at the location Vltava, where the males significantly outnumbered the females (sex ratio - SR $3.60, \chi^{2}=7.3478 ; P=0.0067$ ). The share of sub-adults varied from $25 \%$ in summer at the locality Černá to $57 \%$ in summer at the locality Lužnice (except the locality Vltava in summer, where only 3 specimens (all sub-adult) of A. flavicollis were captured).

In addition 165 specimens of the species Myodes glareolus were trapped, of which 112 individuals (67.9\%) repeatedly, with 27 individual animals captured both during the summer and fall. One individual animal of the species $M$. glareolus was recaptured 11 times. The sexes were little more out of balance in comparison to Apodemus flavicollis. Significantly more females were trapped in summer (SR 0.27, $\chi^{2}=10.9393 ; P=0.0001$ ) as well as in fall (SR 0.33, $\left.\chi^{2}=8.0 ; P=0.0046\right)$ at the locality Lužnice. The locality Vltava also exhibited more females (SR 0.4, $\chi^{2}=3.8571 ; P=0.0495$ ) being in fall. The share of sub-adults varied from $38 \%$ in summer at the locality Malše to $86 \%$ in summer at the locality Černá. The overall share of sub-adults was decisively higher in fall $(\mathrm{F}=5.238 ; P<0.05)$.

\section{Mobility}

Since the representation of A. flavicollis and Myodes glareolus was sufficient in all the localities and both of the seasons, their locomotion activity - mobility - based on the distance between two subsequent captures, could be evaluated. Apodemus flavicollis demonstrated ( $\mathrm{F}=5.934, P<0.05)$ greater mobility $(16.5 \pm 0.7 \mathrm{~m})$ in comparison to Myodes glareolus $(13.8 \pm 0.9 \mathrm{~m})$. The males $(18.0$ $\pm 1.6 \mathrm{~m})$ of $M$. glareolus, were significantly more mobile than the females $(12.5 \pm 0.9 \mathrm{~m})(\mathrm{F}=9.524$, $P<0.05)$. However, no other differences among localities, seasons, or age categories were found for this species.

No differences were determined in mobility between the sexes or subadults/adults for the next most numerous species, Apodemus flavicollis. Neither were found any dissimilarities between summer and fall captures, however, there was a difference in mobility among the localities. The Malše $(23.5 \pm 2.4 \mathrm{~m})$ locality conclusively showed greater mobility $[\mathrm{F}(4.557)=4.9916$; $P=0.00058]$ than either

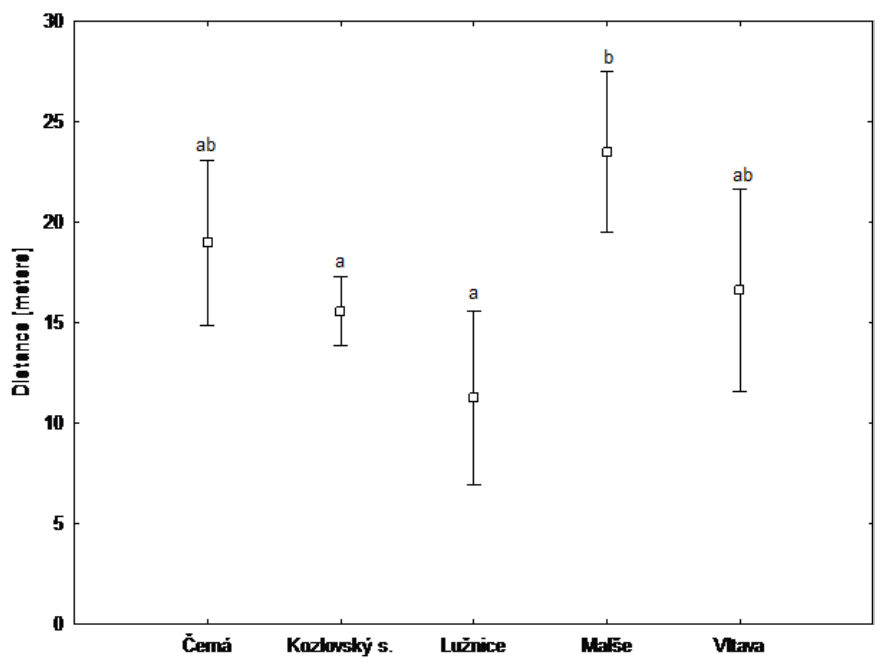

Fig. 2. Average values and $95 \%$ confidence interval of mobility of A. flavicollis. Averages designated by same letters do not vary significantly. Individual animals at the locality Malše showed, on the average, significantly greater level of mobility than at the localities of Lužnice and Kozlovský stream $(\mathrm{F}(4.557)=4.9916 ; P=$ 0.00058; Tukey's post-hoc test, for different number N, $P<0.05)$. 


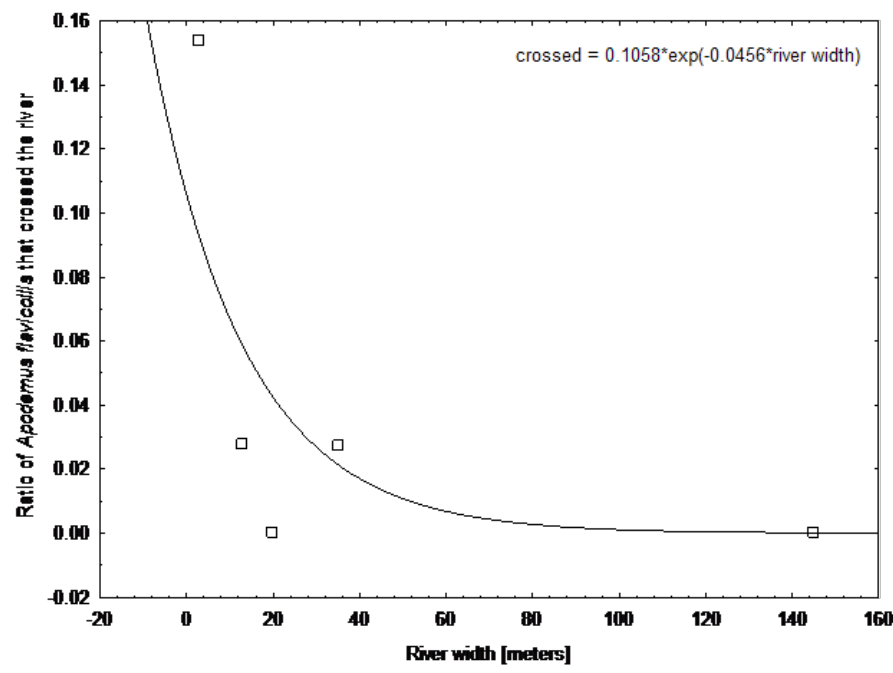

Fig. 3. The graph shows the result of fitting the equation $y=0.1058^{\star} \exp \left(-0.0456^{\star} x\right)$. It shows the dependence of the relative number of stream crossings (y) on the width of the stream (x) for A. flavicollis. The relative number of stream crossings is the proportion of individuals crossing the watercourse to the total number of individuals captured at the locality. at the Kozlovský stream locality $(15.5 \pm 0.8 \mathrm{~m})$ or the Lužnice $(11.2 \pm 1.6$ m) locality - see Fig. 2. Nevertheless regression (log link function) between mobility and the width of the stream was not found $(P=0.76)$.

\section{Stream crossings}

Stream crossings were detected in three localities - Kozlovský stream, Černá and Lužnice. The rivers Černá $(13 \mathrm{~m})$ and Lužnice $(35 \mathrm{~m})$ were crossed one time by adult males $A$. flavicollis, which were marked

in the summer and recaptured three months later, in the fall, when the crossing was determined. The re-crossing of A. flavicollis of the stream was uncovered only at the locality of Kozlovský stream ( $3 \mathrm{~m}$ ) after one crossing. Myodes glareolus and Microtus agrestis were also found to have crossed here one time.

The Kozlovský stream was crossed by 12 individual animals of the species of Apodemus flavicollis, of which 10 re-crossed back once and 5 animals re-crossed repeatedly. Two individual animals crossed the stream in the summer and 10 in the fall. Sex had no effect on the number of stream crossings. The proportion of sub-adult individuals to adults (8:4) was statistically insignificant. The $\chi^{2}$ goodness-of-fit test with Yates' correction therefore showed the existence of barrier effect of the stream for adult specimens even with a very narrow Kozlovský stream $\left(\chi^{2}=\right.$ 5.97; $P=0.015$ ). During the observation period ( 3 months), the number of watercourse crossing had an exponential dependence (power link function) on the width of the stream (Wald Stat. 36.5; $P<0.0001$ ) and on the abundance (Wald Stat. 1116.7; $P<0.0001$ ). Mobility did not influence the number of crossings (Wald Stat. 1.2; $P=0.27$ ) - see Figs 2 and 3.

\section{Discussion}

\section{Communities of small terrestrial mammals along the streams}

Based on the trappings of small terrestrial mammals, it can be stated that a demonstrable effect of the width of the stream was shown, especially in the case of species diversity ( $\left.H^{\prime}\right)$, but 
also for equitability $(E)$. The first working hypothesis was then upheld. Many other parameters which help to create the heterogeneous environment along the watercourse (Forman, Godron, 1993; Jacob, 2003; Wijnhoven et al., 2005), not just the width of the stream alone, play a part in the regression. The relatively large species diversity is not only provided by the migrating individual animals, but is insured by the mosaic of different moisture conditions, which united such animals as Microtus agrestis and M. arvalis, Neomys fodiens and Crocidura suaveolens. The diversity encountered corresponds to above average values in the central European landscape (e.g., Zejda, 1973; Bürger et al., 1987; Bryja, Řehák, 1998; Bryja, Zukal, 2000; Bejček, Štastný, 2003; Rico et al., 2007a; Suchomel, Heroldová, 2004).

Eudominant species were unambiguously Apodemus flavicollis and Myodes glareolus, with overall domination $\mathrm{D}=38.6 \%$, resp. $\mathrm{D}=30.2 \%$. They were, at all localities, captured syntopically, which can be explained by common food resources as presented by Holišová (1969), Obrtel, Holišová (1974). Similar results regarding these species were recorded by Kozakiewicz, M., Kozakiewicz, A. (2008) in a narrow strip of alder woods along a lake adjoining an agrocoenosis and a forest.

M. glareolus, as a species with a significant affinity to the mesophilic and hygrophilic communities, is not only dominant in the floodplain forests of the Danube and Morava (D $=63.3 \%$, Krištofík, 1999) rivers and in floodplains generally (Jacob, 2003), but also in the scree-woods and closed stands (Šmaha, 1996; Reiter et al., 1997), by the creeks (D = 19.8\%, Bürger et al., 1987), at moist locations of lake shores (Kozakiewicz, 1985), on pond dams ( $\mathrm{D}=37.8 \%$, Štastný, 1985) as well as in the extensive reed beds along watercourses (Bejček, Štastný, 2003) and fishponds (Pelikán, 1975). Euryvalence of M. glareolus is also supported by our findings. It was captured regularly in the herbages of Phalaris arundinacea and Carex brizoides, and in the cover of woody plants, usually with sufficient vegetation cover ( $\mathrm{D}=21.8$ 45.7\%), which provides adequate shading (e.g., Zejda, 1973; Pelikán, 1975; Májsky, 1985).

As mentioned earlier, another eudominant species with high abundance was Apodemus flavicollis. It reached the highest values of dominance at the locality Kozlovský stream $(\mathrm{D}=$ $61.2 \%$ ), in a habitat, structurally reminiscent of floodplain forests with high herbage, and offering a food supply (seeds of herbs, fruits and seeds of trees or shrubs, invertebrates) trophically very suitable. A. flavicollis apparently found similar suitable conditions at other localities too. Bryja, Řehák (1998) cite high percentage of dominance ( $\mathrm{D}=71.3 \%)$ in floodplain forests, but Krištofík (1999) registered half as much, both, in hardwood (D = 27.8\%) as well as in softwood $(\mathrm{D}=8.3 \%)$ floodplain forests. In the Vltava locality, with the highest species diversity biotope, the dominance of A. flavicollis was a bit lower (18.8\%). The reason for this was twofold - their low abundance and, mostly, the greater number of Microtus arvalis $(\mathrm{A}=6.9 \%, \mathrm{D}=41.3 \%)$, which favors the drier stream banks with a lower vegetation cover. This riparian strip probably became a migration corridor for one individual from a nearby agrocoenosis. Bryja, Zukal (2000) similarly registered high dominance $(\mathrm{D}=19.6 \%)$ of $M$. arvalis at the edges of the studied habitats, which fulfilled the function of biocorridors. Besides the two above mentioned eudominant species, M. agrestis was represented in almost all the localities, with the highest abundance and dominance $(\mathrm{D}=12.4 \%)$ at the locality Černá, a waterlogged riparian habitat with sedge vegetation as documented by Reiter et al. (1997) as well. 
Apodemus sylvaticus probably also favored the patchy forest, nearby agrocoenosis and riverbank ecotone at the locality Vltava, where it reached quite a high level of dominance $(\mathrm{D}=$ 6.0\%). Micromys minutus was seen only at two locations (Černá, Malše) in riparian herbage.

Shrews, represented by 4 species, with Sorex araneus was commonly spotted in all small mammal communities under observation. Its highest dominance occurred in the locality Vltava $(\mathrm{D}=6.8 \%)$, where it was found in bank vegetation and in surrounding scrub stands. Bürger et al. (1987) cite dominance of up 20\% in riparian stands. Kozakiewicz (1985) also captured this species in emergent and sub-emergent parts of the lake shore. Surprising, due to the presence of watercourses with wetland habitats, insectivores S. minutus and Neomys fodiens belonged to the recedental species. The capture of Crocidura suaveolens $(\mathrm{D}=0.8-0.9 \%)$ at the localities of Lužnice and Vltava was also suprising. The presence of weekend cottages in the nearby vicinity, which creates a suitable synanthropic habitat (e.g., Zima et al., 1999), could be the likely explanation.

\section{Mobility}

Apodemus flavicollis displayed overall greater mobility $(16.5 \mathrm{~m})$ in comparison to Myodes glareolus (13.8 m). Our results correspond to those of Mazurkiewicz, Rajska-Jurgiel (1998), who studied spatial behaviour of both species in forest habitat, and to the findings of Rico et al. (2007b), showing a slightly higher mobility of Apodemus flavicollis negotiating road barriers (A.flavicollis $17.0 \mathrm{~m}$ vs. Myodes glareolus $16.5 \mathrm{~m}$ ). Similarly Bąkowski, Kozakiewicz (1988) and Wolton (1985) state the higher mobility of this species, and the fact that it is related to a greater home-range than that of Myodes glareolus. No difference among the localities or the seasons of capture was found for M. glareolus. Only higher mobility of males was detected. This difference was also observed by Kozakiewicz et al. (2007), with their results pointing at a close connection between mobility of males and reproductive energy.

As seen in Fig. 2, the mobility of Apodemus flavicollis is not the same for all the locations. However, we could not support the hypothesis that mobility along the barrier increases proportionally with its insurmountability in the across direction - in this case the width of the stream. Wolff (1999) considers A. flavicollis as a habitat generalist, which moves easily throughout the patchy habitat. Therefore the documented higher values of mobility measured at the locality of Malše can be related to pattern of habitat, which in the broad vicinity, as compared to the one around the localities of Kozlovský stream and Lužnice, is much more fragmented. Marsh et al. (2001) also states that movement and abundance of the Apodemus species are greatly influenced by landscape parameters such as land use, and distance and connectivity of the forests.

\section{Stream crossings}

Stream crossings as barriers depend on the width of the riverbed, stream-flow and water temperature, and the mobility and specialization of each species (Spackman, Hughes, 1995; Wolff, 1999). When selecting the suitable stretch of the stream, we tried the width of the wa- 
tercourse to be the only important factor, with flow velocity to be roughly the same for all the sites and of the lowest possible value.

Early in the day trappings in the summer and fall should, among other things, assure an acceptable temperature. Per this methodology, A. flavicollis crossed the stream at locations: Kozlovský stream (width 3 m), Černá (13 m), Lužnice (35 m). Though few individual animals crossed the wide watercourses, the generalized linear model showed that the width of the stream had a significant effect on the number of animals that surmounted the barrier. As shown in Fig. 3, an exponential curve fits the best to connect the points indicating the potential of small terrestrial mammals of crossing the stream, since widths around $30 \mathrm{~m}$ are already difficult to surmount (see Hafner, J.C., Hafner, M.S., 1975). The time span of the captures indicates that the crossings of wider watercourses can by observed only after a longer period - up to 3 months.

We paid close attention (see above) to the mobility on the bank, because it can be interpreted as the "engine", which supports river crossings, since it was shown in a study (Rico et al., 2007b) that A. flavicollis and Myodes glareolus behaved in such way when crossing roads of various widths. Regression of crossings of the streams and mobility in Apodemus flavicollis, however, was not proven in our study.

A similar stimulus to cross the river can also be population abundance, a situation often described while studying population cycles of small terrestrial mammals. In this state, high rate of emigration is seen from the overcrowded area (e.g., Ims, Andreassen, 2005; Smith, Batzli, 2006), and even difficult to surmount barriers, including wider watercourses, are overcome by the animals. We expressed the population abundance relatively - as abundance (A), which had the effect in overcoming the watercourse obstacles under the conditions seen in our study. In the study of A. flavicollis and Myodes glareolus and their crossings of roads a similar situation is observed, even though no special attention was paid to the effect of population density on surmounting of barriers (Rico et al., 2007b).

We captured only adult specimens, which in crossed wider streams, perhaps due to their greater experience and mass (e.g., Giannoni et al., 1994; Cook et al., 2001; Nicolas, Colyn, 2006) they were able to cope with this situation. At the Kozlovský stream locality both adults as well as sub-adults were, of course, captured. It can be assumed that young individuals were pushed out of the area and forced to emigrate across the narrow stream (e.g., Ims, Andreassen, 2005; Smith, Batzli, 2006). They were, probably, as shown by the proportion of 8:4 (see Results) successful. On the other hand, adult individuals considered the stream to be a fixed boundary at the edge of their home-range, something not to be frequently crossed. This fact can therefore symbolize more a filtration rather than a barrier.

For M. glareolus, with a much lower mobility, the numbers of stream crossings was much lower. Only one adult female, captured on the opposite bank of Kozlovský stream (3 m), can demonstrate the presence of a pronounced boundary and it is not effected at all by the fact that the abundance of Clethrionomys glareolus is three times lower than that of Apodemus flavicollis (see Table 2).

In the case of Myodes glareolus, we really cannot even talk about an obstacle ( 3 m wide stream), but rather about a boundary limiting movement. We have an analogy in the study of narrow forest roads conducted by Bąkowski, Kozakiewicz (1988), Aars et al. (1998), Rico et al. (2007a). 
Crossing a narrow stream may include one more aspect. It is probably not only if individuals of a certain species are young or old, but rather what their personality is like - if they are not afraid of new environment and exploration is not unduly stressful for them. Perhaps even such a narrow stream easily filters individuals of different personality traits, as is currently explored in a laboratory setting (e.g., Martin, Réale, 2008; Lantová et al., 2011).

The genetic analysis shows that watercourses on the order of tens of meters do not have to be major barriers and overcoming them, as shown above, is a matter of months. Nevertheless, even here it is possible to observe a certain shift as in allelic composition of microsatellite loci. Much more observable are the differences in populations of small terrestrial mammals (see Aars et al., 1998; Gerlach, Musolf, 2000; Lugon-Moulin, Hausser, 2002; Kozakiewicz et al., 2009) when dealing with wide bodies of water (hundreds of meters) and especially with a strong current.

\section{Conclusion}

The degree of the barrier-width of the stream, had an effect on species diversity and equitability of the communities of the watercourse banks.

In riparian habitats and adjacent forest stands along the streams, Apodemus flavicollis and Myodes glareolus were the dominant species.

The width of the stream had no effect on the terrestrial mobility of Apodemus flavicollis and Myodes glareolus.

During the period of three months, Apodemus flavicollis crossed streams of up to tens of meters wide. The number of individual animals, which are able to cross the river decreases exponentially. Greater abundance contributes to a greater number of crossings.

\section{Acknowledgements}

We are grateful to Richard Klee, M.Sc. for help with the translation manuscript and constructive comments. We wish to thank also J. Zikeš for assistance in the field work.

\section{References}

Aars, J., Ims, R.A., Liu, H.P., Mulvey, M. \& Smith M.H. (1998). Bank voles in linear habitats show restricted gene flow as revealed by mitochondrial DNA (mtDNA). Mol. Ecol., 7, 1383-1389. DOI: 10.1046/j.1365-294x.1998.00487.x.

Andersen, D.C., Wilson, K.R., Miller, M.S. \& Falck M. (2000). Movement patterns of riparian small mammals during predictable floodplain inundation. J. Mammal., 81(4), 1087-1099. DOI: 10.1644/1545-1542(2000)081<1087:MP ORSM $>2.0 . \mathrm{CO} ; 2$.

Bąkowski, C. \& Kozakiewicz M. (1988). The effect of forest road on bank vole and yellow-necked mouse populations. Acta Theriol., 33, 345-353.

Begon, M., Harper, J.L. \& Townsend C.R. (1990). Ecology: individuals, populations and communities. Blackwell Scientific Publications.

Bejček, V. \& Štastný K. (2003). The importance of floodplains for terrestrial vertebrates (in Czech). In K. Prach, D. Pithart \& T. Francírková (Eds.), Ekologickéfunkce a hospodáření v ř́icních nivách (pp. 30-36). Třeboň: Botanický ústav AV ČR.

Bennett, A.F. (2003). Linkages in the landscape: the role of corridors and connectivity in wildlife conservation. Gland, Switzerland and Cambridge: IUCN.

Bryja, J. \& Řehák Z. (1998). Community of small terrestrial mammals (Insectivora, Rodentia) in dominant habitats of the Protected Landscape Area of Poodří (Czech Republic). Folia Zool., 47(4), 249-260. 
Bryja, J., Zukal, J., 2000: Small mammal communities in newly planted biocorridors and their surroundings in southern Moravia (Czech Republic). Folia Zool., 49, 3: 191-197.

Bürger, P., Anděra, M. \& Zbytovský P. (1987). Mammals of Blanský les-Šumava foothills (in Czech). Lynx (Praha), 23, 5-42.

Cook, W.M., Timm, R.M. \& Hyman D.E. (2001). Swimming ability in three Costa Rican dry forest rodents. Rev. Biol. Trop., 49(3-4), 1177-1181.

Forman, R.T.T. \& Godron M. (1993). Landscape ecology (in Czech). Praha: Academia.

Gaines, M.S. \& McClenaghan L.R. (1980). Dispersal in small mammals. Annu. Rev. Ecol. Syst., 11, 163-196. http:// www.jstor.org/stable/2096906

Gerlach, G. \& Musolf K. (2000). Fragmentation of landscape as a cause for genetic subdivision in bank voles. Conserv. Biol., 14, 1066-1074. DOI: 10.1046/j.1523-1739.2000.98519.x.

Giannoni, S.M., Borghi, C.E. \& Martinezrica J.P. (1994). Ability of the mediterranean pine vole Microtus (Terricola) duodecimcostatus. Acta Theriol., 39(3), 257-265.

Hafner, J.C. \& Hafner M.S. (1975). Water as a potential barrier to dispersal in Microdipodops. J. Mammal., 56, 911-914. DOI: 10.2307/1379663.

Hirota, T., Hirohata, T., Mashima, H., Satoh, T. \& Obara Y. (2004). Population structure of the large Japanese field mouse, Apodemus speciosus (Rodentia: Muridae), in suburban landscape, based on mitochondrial D-loop sequences. Mol. Ecol., 13, 3275-3282. DOI: 10.1111/j.1365-294X.2004.02324.x.

Holišová, V. (1969). Vertical movements of some small mammals in a forest. Zoologické Listy, 18, 121-141.

Ims, R.A. \& Andreassen H.P. (2005). Density-dependent dispersal and spatial population dynamics. Proc. R. Soc. Biol. Sci. Ser. B, 272(1566), 913-918. DOI: 10.1098/rspb.2004.3025.

Jacob, J. (2003). The response of small mammal populations to flooding. Mamm. Biol., 68, 102-111. DOI:10.1078/1616-5047-00068.

Keller, L.F. \& Waller D.M. (2002). Inbreeding effects in wild population. Trends Ecol. Evol., 17, 230-241. DOI: 10.1016/ S0169-5347(02)02489-8.

Kozakiewicz, A. (1985). Lakeside communities of small mammals. Acta Theriol., 30(9), 171-191.

Kozakiewicz, M., Chołuj, A. \& Kozakiewicz A. (2007). Long-distance movements of individuals in a free-living bank vole population: an important element of male strategy. Acta Theriol., 52(4), 339-348. DOI: 10.1007/ BF03194231.

Kozakiewicz, M., Kozakiewicz, A., 2008: Long-term dynamics and biodiversity changes in small mammal communities in a mosaic of agricultural and forest habitats. Ann. Zool. Fenn., 45, 263-269.

Kozakiewicz, M., Gortat, T., Panagiotopoulou, H., Gryczyńska-Siemiątkowska, A., Rutkowski, R., Kozakiewicz, A. \& Abramowicz K. (2009). The spatials genetic structure of bank vole (Myodes glareolus) and yellow-necked mouse (Apodemus flavicollis) populations: The effect of distance and habitat barriers. Anim. Biol., 59, 169-187. DOI: $10.1163 / 157075609 X 437691$.

Krištofík, J. (1999). Small mammals in floodplain forests. Folia Zool., 48(3), 173-184.

Lantová, P., Š́chová, K., Sedláček, F. \& Lanta V. (2011). Determining behavioural syndromes in voles - the effects of social environment. Ethology, 117, 124-132. DOI: 10.1111/j.1439-0310.2010.01860.x.

Lugon-Moulin, N. \& Hausser J. (2002). Phylogeographical structure, postglacial recolonization and barriers to gene flow in the distinctive Valais chromosome race of the common shrew (Sorex araneus). Mol. Ecol., 11, 785-794. DOI: 10.1046/j.1365-294X.2002.01469.x.

Májsky, J. (1985). Small land mammals of flood forests and of the wind break of the upper part of the Žitny ostrov island (in Slovak). Bratislava: Veda, vydavatel'stvo SAV.

Marsh, A.C.W., Poulton, S. \& Harris S. (2001). The yelow-necked mouse Apodemus flavicollis in Britain: status and analysis of factors affecting distribution. Mammal Rev., 31(3-4), 203-227. DOI: 10.1111/j.13652907.2001.00089.x.

Martin, J.G.A. \& Réale D. (2008). Temperament, risk assessment and novelty in eastern chipmunks, Tamias striatus. Anim. Behav., 75, 309-318. DOI: 10.1016/j.anbehav.2007.05.026.

Mazurkiewicz, M. \& Rajska-Jurgiel E. (1998). Spatial behaviour and population dynamics of woodland rodents. Acta Theriol., 43(2), 137-161.

Merriam, G., Kozakiewicz, M., Tsuchiya, E. \& Hawley K. (1989). Barriers as boundaries for metapopulations and demes of Peromyscus leucopus in farm landscapes. Landsc. Ecol., 2, 227-235. DOI: 10.1007/BF00125093.

Nicolas, V. \& Colyn M. (2006). Swimming ability of 5 species of African rainforest murid rodents in relation to their habitat preferences. Zool. Stud., 45(2), 264-268. 
Obrtel, R. \& Holišová V. (1974). Trophic niches of Apodemus flavicollis and Clethrionomys glareolus in a lowland forest. Acta Scientarium Naturalium Academiae Scientiarum Bohemoslovacae Brno, 8, 1-37.

Pelikán, J. (1975). Mammals of Nesyt fishpond, their ecology and production. Acta Scientarium Naturalium Academiae Scientiarum Bohemoslovacae Brno, 9(12), 1-45.

Pocock, M.J.O., Hauffe, H.C. \& Searle J.B. (2005). Dispersal in house mice. Biol. J. Linn. Soc., 84(3), 565-583. DOI: 10.1111/j.1095-8312.2005.00455.x.

Reiter, A., Hanák, V., Benda, P. \& Obuch J. (1997). Mammals of the Podyjí National Park (in Czech). Lynx (Praha), 28: 5-141.

Rico, A., Kindlmann, P. \& Sedláček F. (2007a). Barrier effects of roads on movements of small mammals. Folia Zool., 56(1), 1-12.

Rico, A., Kindlmann, P. \& Sedláček F. (2007b). Road crossing in bank voles and yellow-necked mouse. Acta Theriol., 52, 85-94. DOI: 10.1007/BF03194203.

Rico, A., Kindlmann, P. \& Sedláček F. (2009). Can the barrier effect of highways cause genetic subdivision in small mammals? Acta Theriol., 54, 297-310. DOI: 10.4098/j.at.0001-7051.068.2008.

Rodriguez, A., Crema, G. \& Delibes M. (1996). Use of non-wildlife passages across a high speed railway by terrestrial vertebrates. J. Appl. Ecol., 33, 1527-1540. DOI: 10.2307/2404791.

Rosenberg, D.K., Noon, B.R. \& Meslow E.Ch. (1997). Biological corridors: form, function, and efficacy. BioScience, 47(10), 677-687. DOI: 10.2307/1313208.

Smith, J.E. \& Batzli G.O. (2006). Dispersal and mortality of prairie voles (Microtus ochrogaster) in fragmented landscapes: a field experiment. Oikos, 112(1), 209-217. DOI: 10.1111/j.0030-1299.2006.13431.x.

Spackman, S.C. \& Hughes J.W. (1995). Assesment of minimum stream corridor width for biological conservation: species richness and distribution along mid-order stress in Vermont, USA. Biol. Conserv., 71, 325-332. DOI: 10.1016/0006-3207(94)00055-U.

Stenseth, N.C. \& Lidicker W.Z., Jr. (1992). Animal dispersal: small mammals as a model. London: Chapman and Hall.

Suchomel, J. \& Heroldová M. (2004). Small terrestrial mammals in two types of forest complexes in intensively managed landscape of South Moravia (The Czech Republic). Ekológia (Bratislava), 23(4), 377-384.

Šmaha, J. (1996). Notes on the mammal fauna of the Křivoklátsko Biosphere Reserve (in Czech). Lynx (Praha), 27, 37-57.

Štastný, K. (1985). Birds and mammals of the pond dikes around Třeboň: use of landscape ecology (in Czech). České Budějovice: Jihočeské Muzeum v Českých Budějovicích.

Wijnhoven, S., van der Velde, G., Leuven, R.S.E.W. \& Smits A.J.M. (2005). Flooding ecology of voles, mice and shrews: the importance of geomorphological and vegetational heterogeneity in river floodplains. Acta Theriol., 50, 453-472. DOI: 10.1007/BF03192639.

Wolff, J.O. (1999). Behavioral model systems. In G.W. Barrett \& J.D. Peles (Eds.), Landscape ecology of small mammals (pp. 11-40). New York: Springer-Verlag.

Wolton, R.J. (1985). Spatial distribution and movements of wood mice, yellow-necked mice and bank voles. Symp. Zool. Soc. Lond., 55, 249-275.

Zar, J.H. (1999). Biostatistical analysis. New Jersey: Prentice Hall.

Zejda, J. (1973). Small mammals in certain forest type groups in Southern Moravia. Folia Zool., 22, 1-13.

Zima, J., Obuch, J., Kopcová-Klodová, G., Kovařík, M. \& Gaisler J. (1999). Insectivores and rodents of Moravian karst and surrounding areas (in Czech). Lynx (Praha), 29, 77-94. 